\section{DESCRIPTION OF THREE NEW SPECIES OF PSILOCERA WALKER FROM INDIA, WITH A KEY TO THE ORIENTAL SPECIES (HYMENOPTERA: Chalcidoidea: Pteromalidae)}

\section{P.M. Sureshan}

Zoological Survey of India, Western Ghats Regional Centre, Jafferkhan Colony, Eranhipalam.P.O., Kozhikode, Kerala 673006, India

pmsuresh43@yahoo.com

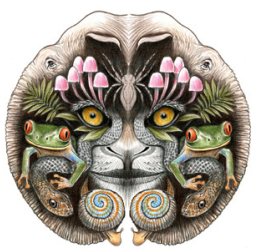

ISSN

Online 0974-7907 Print 0974-7893
Abstract: Three new species of Psilocera Walker (Hymenoptera: Pteromalidae), $P$. keralensis sp. nov., $P$. intermedia sp. nov. and $P$. namdaphaensis sp. nov., are described. The latter two new species were earlier described by Sureshan (2011) in an electronic publication not recognized by the ICZN and have, therefore, become unavailable names. The affinities of the new species with the other known species are discussed. A key to the oriental species of Psilocera is also provided.

Keywords: Hymenoptera, new species, Psilocera, Pteromalidae.

Abbreviations: F1-F6 = funicular segments 1 to 6 ; ICZN = International Commission on Zoological Nomenclature; $\mathrm{MV}=$ marginal vein; $\mathrm{OOL}=$ ocellocular distance; $\mathrm{PMV}=$ post- marginal vein; $\mathrm{POL}=$ post-ocellar distance; SMV = submarginal vein; STV = stigmal vein; T1-T5 = gastral tergites 1-5; ZSIK = Zoological survey of India, Western Ghats Regional Centre, Calicut, India.
The genus Psilocera Walker (Hymenoptera: Pteromalidae) is known from 30 described species throughout the world, with nine species from the oriental region (Noyes 2012). The oriental species of this genus were reviewed by Sureshan (2011). Other contributions on the taxonomy of the oriental Psilocera are by Rao (1981), Sureshan (2000, 2001), Sureshan \& Narendran (1995) and Narendran \& Kumar (2009). Among the described species of Psilocera from India, two names, viz., Psilocera intermedia Sureshan, 2011, and Psilocera namdaphaensis Sureshan, 2011, were published in an e-journal and have become 'unavailable' names, as publications of new names prior to 2012 in e-journals [without a print edition] were not recognized by the International Commission of Zoological Nomenclature (ICZN 1999, 2012). Therefore, both these species are described here as new species to make the names available. In addition to these two species, one new species of Psilocera is also described based on the collections made from the forested tracts of southern Western Ghats of Kerala. Affinities of the new species

DOI: http://dx.doi.org/10.11609/JoTT.o3654.5851-7 | ZooBank: urn:Isid:zoobank.org:pub:2DB6DFC5-771A-40FE-A51A-516F95285083

Editor: Mohammad Hayat, Aligarh Muslim University, Aligarh, India.

Date of publication: 26 June 2014 (online \& print)

Manuscript details: Ms \# 03654 | Received 07 June 2013 | Final received 13 June 2014 | Finally accepted 14 June 2014

Citation: Sureshan, P.M. (2014). Description of three new species of Psilocera Walker from India, with a key to the Oriental species (Hymenoptera: Chalcidoidea: Pteromalidae). Journal of Threatened Taxa 6(6): 5851-5857; http://dx.doi.org/10.11609/JoTT.03654.5851-7

Copyright: (C) Sureshan 2014. Creative Commons Attribution 4.0 International License. JoTT allows unrestricted use of this article in any medium, reproduction and distribution by providing adequate credit to the authors and the source of publication.

Funding: The work is based on the annual research programme of Zoological Survey of India, WGRC, Calicut ( Ministry of Environment \& Forests, Govt. of India).

Competing Interest: None.

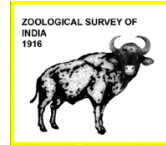

Acknowledgements: I am grateful to Dr. K. Venkataraman, Director, Zoological Survey of India, Kolkata for providing the facilities for the work and constant encouragement. I am also thankful to Sri. K. Nikhil, research scholar, Zoological Survey of India, Western Ghat Regional Centre, Calicut for the helps rendered in photography. Thanks are also due the Chief Wildlife Warden, Kerala and the forest officials of Periyar Tiger Reserve for granting permission for faunal survey and collection and the helps rendered during field work. 
with the other known species are discussed and a key to the oriental species of Psilocera is provided.

\section{Psilocera namdaphaensis sp. nov.}

(Image 1)

urn:Isid:zoobank.org:act:84478FA5-1A03-4589-906E-FA053906041D

Psilocera namdaphaensis Sureshan, 2011. Online publication. Name not available according to ICZN (2012).

\section{Material examined}

Holotype: (ZSIK \# ZSI/WGRS/IR-INV/2070), female, 9.xi.2009, 27031'31.1"N \& 96030'20.7"E, way to Daphabum, Firmbase Road, Namdapha National Park, Arunachal Pradesh, India, coll. P.M. Sureshan.

Paratypes: (ZSIK \# ZSI/WGRS/IR-INV/2071, 2072) two females, 11.xi.2009, 27032'20.3"N \& 96029'17.5”E, way to Ranijheel, Namdapha National Park, Arunachal Pradesh, India, coll. P.M. Sureshan.

Female: Holotype. Length, 3.0mm. (Range 2.8-3.0 $\mathrm{mm}$ ). Head and mesosoma black without metallic reflection, gaster brownish-black with metallic bluish reflection dorsally. Antenna with scape, pedicel and F1 testaceous, remainder brownish-black, upper third of scape darker; eye violet black; ocelli brown; mandible brown. Tegula brown, wings hyaline, veins and pubescence brown. Coxae concolorous with mesosoma, fore femora brown, rest of legs testaceous with tips of tarsi brown.

Head: In dorsal view, $2.21 \times$ as broad as long; POL

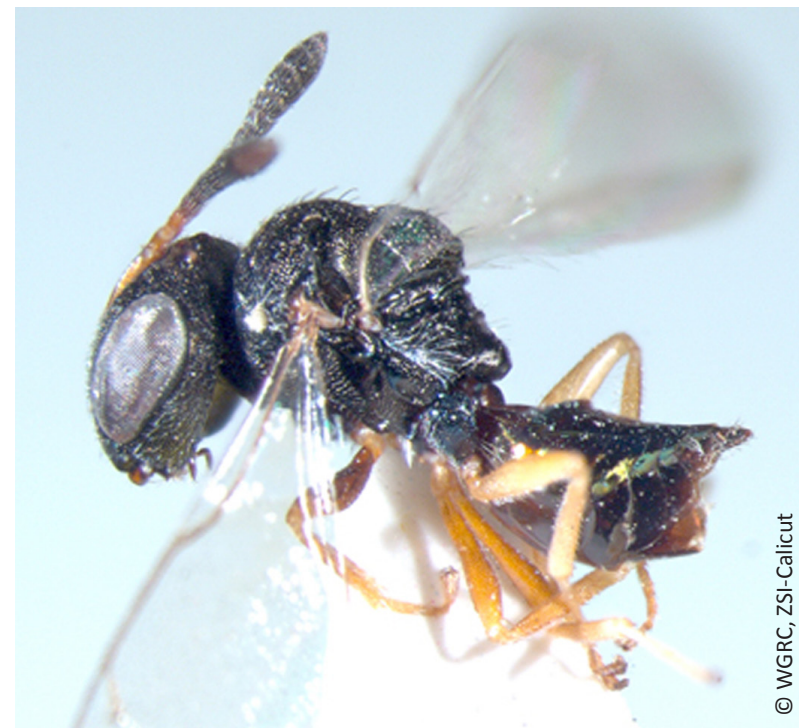

Image 1. Psilocera namdaphaensis sp. nov. Female body in profile
$0.9 \times$ OOL; temple $0.5 \times$ eye height; vertex sharply declivitous; head, in frontal view, width $1.3 \times$ height; eyes separated by $1.5 \times$ their height at the level of toruli; malar space $0.6 \times$ eye height in front view; anterior margin of clypeus with two distinct teeth, radiately striated, striae reaching almost up to base of eye; face moderately reticulate, except for a broad shining area above clypeus; pubescence white, sparse, denser on lower part of face; scrobe deep, reaching median ocellus. Antenna inserted below middle of face; scape just short of reaching median ocellus by a distance which is slightly less than its diameter; scape $0.7 \times$ eye length; pedicel as long as F1; pedicel plus flagellum $0.9 \times$ head width; flagellum strongly clavate; anelli transverse, second little longer than first; F1 as long as F2; all funicular segments with one row of long sensillae; F1-F3 longer than broad, equal, F4 quadrate, a little shorter than F3; F5-F6 transverse, a little shorter than F4; clava $2 \times$ as long as broad, a little shorter than four preceding segments combined, sutures of club oblique, clearly distinct, micropilosity area reaching base of third segment.

Mesosoma: Highly convex, sparsely pubescent and with sparse brown bristles. Prontoal collar finely reticulate, anteriorly carinate in the middle. Mesoscutum and scutellum distinctly reticulate punctuate. Mesoscutum 2.3x as broad as long with notauli incomplete. Scutellum as long as mesoscutum, without any conical projection; frenum clearly marked. Axilla and axillula finely reticulate. Dorsellum narrow, very finely reticulate. Propodeum medially $0.8 \times$ as long as scutellum, in dorsal view $2.4 \times$ as broad as long; propodeum finely reticulate, median carina and costula distinct and complete; plicae indicated only in anterior half; spiracles long, oval, almost touching hind margin of metanotum; post-spiracular sulcus deep, callus with long thick white pubescence. Prepectus small, narrow, fine, as long as tegula. Mesopleuron moderately reticulate with a broad triangular shiny area below hind wings. Lower half of metapleuron finely reticulate, upper half moderately reticulate. Forewing $2.3 \times$ as long as broad; marginal fringe very small, almost indistinct; pubescence moderate; basal cell open below with 2 or 3 scattered hairs at the tip, basal hairline indicated; costal cell completely hairy on the dorsal surface; speculum open below. Relative lengths of SMV, 49; MV, 32; STV, 11; PMV, 22. Legs slender; hind coxa densely hairy on antero-lateral margins, $1.3 \times$ as long as broad; femora $5 \times$ as long as broad; tibiae as long as femora; hind tibia with two spurs.

Metasoma: Petiole distinct; gaster lanceolate, 
shorter than mesosoma $(0.8 \times)$, dorsally collapsing, and, in dorsal view $2.1 \times$ as long as broad; hind margins of T1T3 deeply incised medially, T4 emarginate.

Male: Unknown.

Host: Unknown. Collected from leaf litter on forest floor.

\section{Etymology}

Named after the locality, Namdapha National Park (Arunachal Pradesh) from where the specimens were collected.

\section{Remarks}

In the key to the western European species of Psilocera (Graham, 1992) the new species runs to couplet five with $P$. crassispina (Thomson) and $P$. confusa Graham. In having strongly clavate antenna, clava with micropilosity area reaching two third of length (up to base of third segment), F1 as long as pedicel, POL 0.9x $\mathrm{OOL}$ and larger body size, the new species resembles $P$. crassispina, but differs from it in having forewing with basal cell bare, at most with 1-2 setae; antenna with scape, pedicel, anelli, F1 and F2 partly testaceous (In P. crassispina: forewing with basal cell pilose with 7-16 setae; antenna with scape pedicel and anelli red with pedicel slightly infuscate dorsally). The new species differs from $P$. confusa in having POL $0.9 \times \mathrm{OOL}$, and body size larger, $2.8-3.0 \mathrm{~mm}$. (In P. confusa: POL 1.0-1.5×OOL, body smaller, $1.7-2.8 \mathrm{~mm}$ ). Among the oriental species it resembles $P$. vinayaki Sureshan \& Narendran in general morphology but differs from it by the characters given in the key.

\section{Psilocera intermedia sp. nov.} (Image 2)

urn:Isid:zoobank.org:act:EB5902FD-5951-41E6-8D7D-46FE4EE4F434

Psilocera intermedia Sureshan, 2011. Online publication. Name not available according to ICZN (2012)

\section{Material examined}

Holotype: (ZSIK \# ZSI/WGRS/IR-INV/2073), female, 13.xi.2009, 27032'20.3"N \& $96^{\circ} 29^{\prime} 17.5^{\prime \prime} \mathrm{E}$, way to Ranijheel, Firm base road, Namdapha National Park, Arunachal Pradesh, India, coll.P.M.Sureshan.

Paratype: (ZSIK \# ZSI/WGRS/IR-INV/2074), 12.xi.2009, one male, same data as that of holotype except date of collection.

Female (Holotype): Length, $3.0 \mathrm{~mm}$. Head black; eye dark cupreous. Antenna with scape, pedicel and anelli testaceous, remainder brown; eyes dark cupreous.

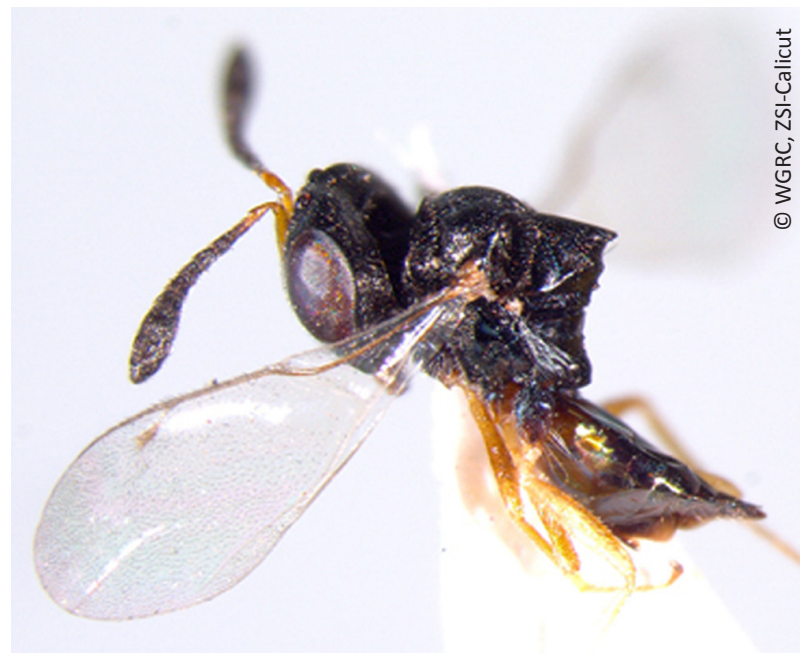

Image 2. Psilocera intermedia sp. nov. Female body in profile

Mesosoma black; tegula brown; coxae, except middle one, concolorous with mesosoma; middle coxa brownish; remainder of legs testaceous with tips of tarsi brown. Wings hyaline, veins and pubescence brown. Gaster brownish-black with metallic bluish reflection.

Head: Face moderately reticulate except for a broad shining area above clypeus; pubescence white, sparse, denser on lower part of face; head, in dorsal view, $2.3 \times$ as broad as long; POL $1.4 \times \mathrm{OOL}$; temple length $0.5 \times$ eye length; vertex declivitous; head, in front view, width $1.3 \times$ height; eyes separated $1.3 \times$ their height at the level of toruli; malar groove distinct; malar space $0.54 \times$ eye height; anterior margin of clypeus with two distinct teeth, radiately striated, striae reaching almost up to base of eye; scorbes deep, reaching median ocellus. Antenna inserted below middle of face; scape hardly reaching median ocellus, length $0.73 \times$ eye height; pedicel almost twice as long as F1; pedicel plus flagellum $0.9 \times$ head width; flagellum strongly clavate; anelli transverse, second slightly longer than first; F1 $0.8 \times \mathrm{F} 2$ which is almost equal to F3; F4 and F5 equal, a little shorter than F3; F6 shortest; clava slightly longer than four preceding segments combined, with broad area of micropilosity reaching base of third segment, and sutures strongly oblique.

Mesosoma: Highly convex, sparsely pubescent and with sparse brown bristles. Prontoal collar finely reticulate, anteriorly carinate in the middle. Mesoscutum and scutellum distinctly reticulate punctuate. Mesoscutum 2.1× as broad as long, with notauli incomplete. Scutellum with a strong finger nail like tip, medially as long as mesoscutum (base to tip of finger nail); frenum clearly separated. Axilla and 
axillula finely reticulate. Dorsellum narrow, very finely reticulate. Propodeum medially $2.9 \times$ as broad as long, and finely reticulate; median carina and costula fine but distinct, median carina interrupted by costula; plicae indicated only in anterior half; spiracle small, oval, separated from hind margin of metanotum by its own diameter, post-spiracular sulcus distinct, not deep; callus with long thick white pubescence. Prepectus small, narrow, fine, as long as tegula. Mesopleuron moderately reticulate with a broad triangular shiny area below wings. Metapleuron finely reticulate. Forewing $2.2 \times$ as long as broad; marginal fringe very small, almost indistinct; pubescence moderate; basal cell open below without hairs, basal hairline indicated by few hairs; costal cell hairy on the upper half, which is complete at tip, speculum open below. Relative lengths of SMV, 51; MV, 30; STV, 10.5; PMV, 26. Legs slender; hind coxa densely hairy on anterio-lateral margins, a tuft of long white hairs present in the distal half of postero-lateral margin, $1.6 \times$ as long as broad. Relative lengths of hind coxa 18 , femur 40 , tibia 43.

Metasoma: Petiole not distinct; gaster short, lanceolate, dorsally collapsing, $2.3 \times$ as long as broad, $0.7 \times$ as long as rest of body and $1.4 \times$ as long as hind tibia; hind margin of T1-T3 incised medially, T4 emarginate.

Male: Length, $1.7 \mathrm{~mm}$. Resembles female except for the small body size and the antennal structure. Antenna with two short anelli and pedunculate funicular segments each bearing two whorls of long hairs; gaster collapsing.

\section{Etymology}

The species name derived from the intermediate nature of morphology with the other two species compared (see remarks below).

\section{Remarks}

Among Psilocera species with a conical hump on scutellum, $P$. clavicornis (Ashmead), P. intermedia sp. nov. and $P$. neoclavicornis Narendran \& Girish Kumar, share a long and projecting finger nail-tip on the scutellum. The new species closely resembles $P$. clavicornis, but differs from it in having the forewing with basal cell open below; MV short, $2.8 \times$ STV; gaster short, only $0.7 \times$ as long as rest of body and $1.4 \times$ as long as hind tibia; antenna with only scape, pedicel and anelli testaceous and rest brownish-black, and F2 0.8× F1 (In $P$. clavicornis: forewing with basal cell closed below; MV long, 3.4× STV; gaster long, $1.9 \times$ as long hind tibia and $0.8 \times$ as long as rest of the body; antenna with scape, pedicel, F1and F2 testaceous and F2 as long F1).
The new species also resembles P.neoclavicornis in general morphology, but neoclavicornis differs from it in having shorter antennae with scape hardly reaching median ocellus, clava shorter than four preceding segments combined, scape pedicel anelli and most of F1 testaceous and rest dark brown, finger nail tip of scutellum slightly shorter, forewing with MV long, 3.14× as long as STV, and gaster long $1.72 \times$ as long as hind tibia and $0.9 \times$ as long as rest of the body.

\section{Psilocera keralensis sp. nov.}

(Images 3-7)

urn:Isid:zoobank.org:act:C8A1DC88-A6D9-4589-B339-8B844658C7B0

\section{Material examined}

Holotype: (ZSIK \# ZSI/WGRS/IR-INV/2630),

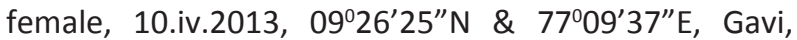
Pathanamthitta District, Kerala, India, coll. P.M. Sureshan.

Paratype: (ZSI/WGRS/IR-INV/2631), one male, same data as that of holotype.

Female: (Holotype) Length, $2.2 \mathrm{~mm}$. Head black; eyes light grey; ocelli silvery. Antenna with scape, pedicel and anelli testaceous, remainder black. Mesosoma black; tegula brown. Wings hyaline, veins pale brown, pubescence brown. Coxae concolorous with mesosoma; hind coxa slightly brownish-black; fore and mid femora, basal half of fore and mid tibia brown, remainder of legs testaceous with tips of tarsi brown. Gaster with metallic blue reflection distinct on $\mathrm{T} 1$ dorsally.

Head (Images 3,4): $1.2 \times$ as broad as mesosoma; width, in dorsal view, $2.15 \times$ length, and in front view width $1.14 \times$ height; anterior margin of clypeus projecting

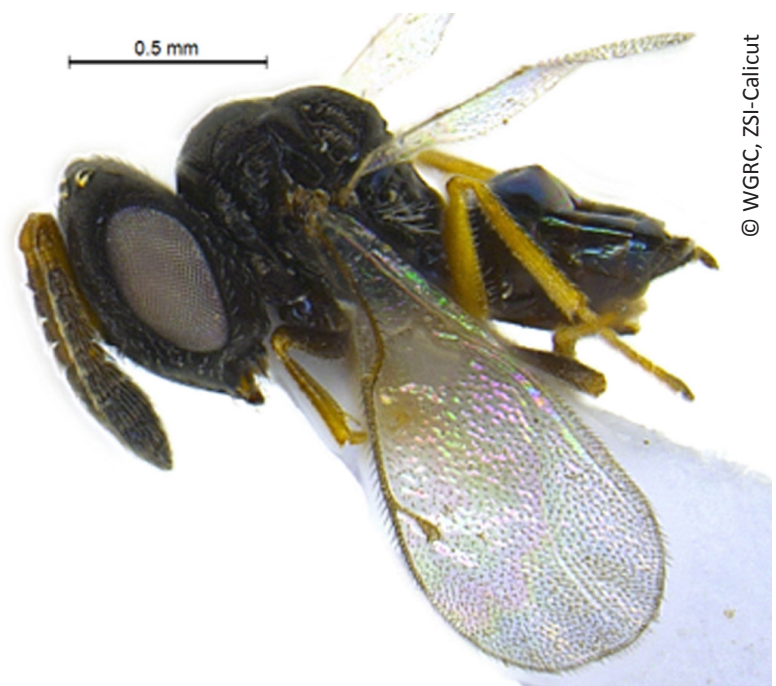

Image 3. Psilocera keralensis sp. nov. Female body profile 


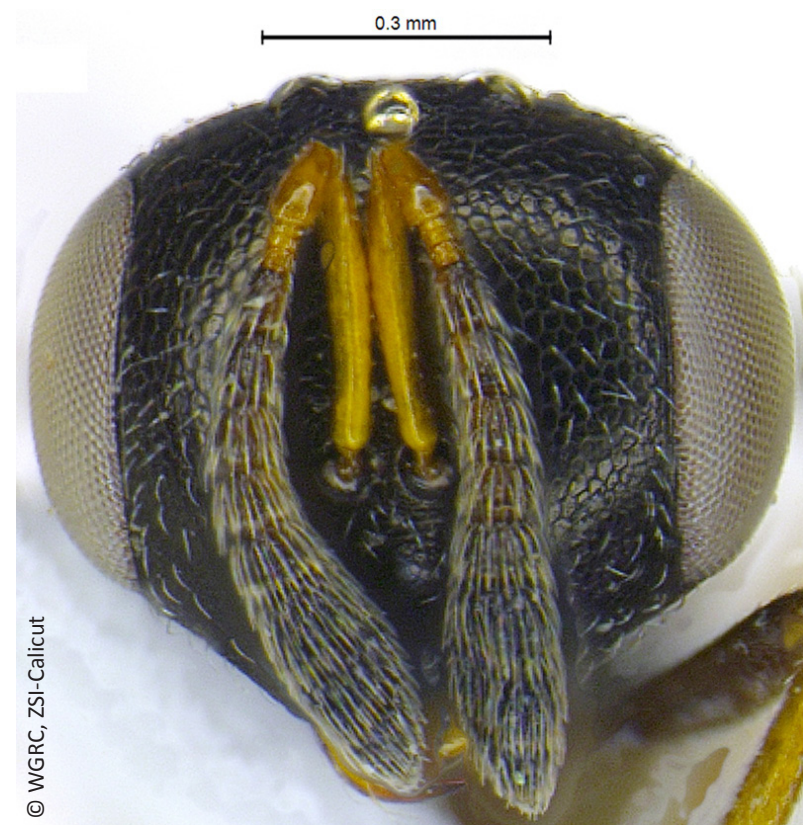

Image 4. Psilocera keralensis sp. nov. Head in front view

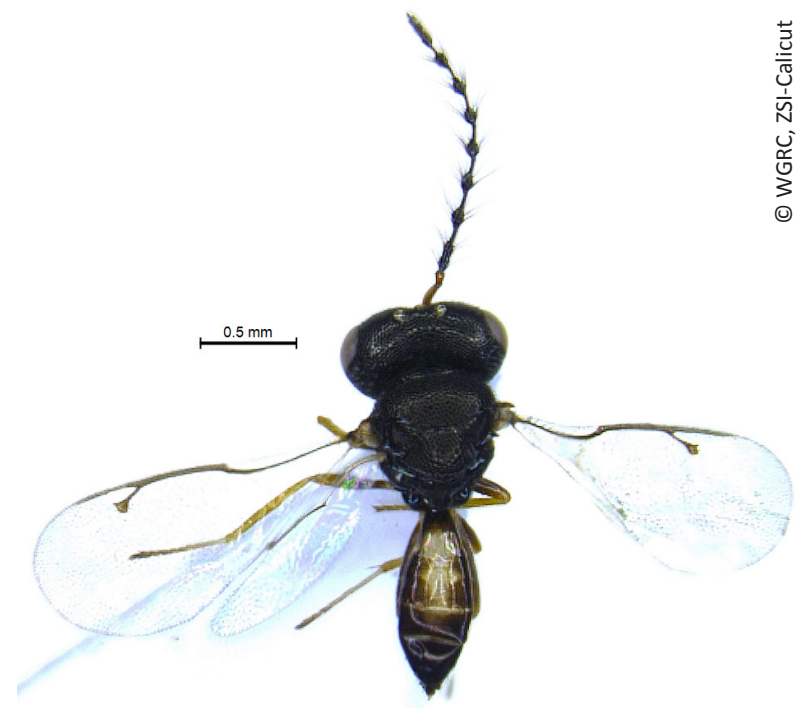

Image 6. Psilocera keralensis sp. nov. Male body in dorsal view.

a little below lower level of head, distinctly bidentate; POL slightly longer than OOL (12.5: 11.5); temple length $2 \times$ eye height; scrobe deep; malar sulcus distinct; eye height $2 \times$ width; head moderately reticulate with moderate, sparse, white pubescence; reticulation on gena and vertex fine, round area below toruli smooth; clypeus radiately striated, striae reaching beyond clypeal margin to paraclypeal area. Antenna inserted below middle of face, above lower ocular line; pedicel plus flagellum length $0.9 \times$ head width; anelli transverse,

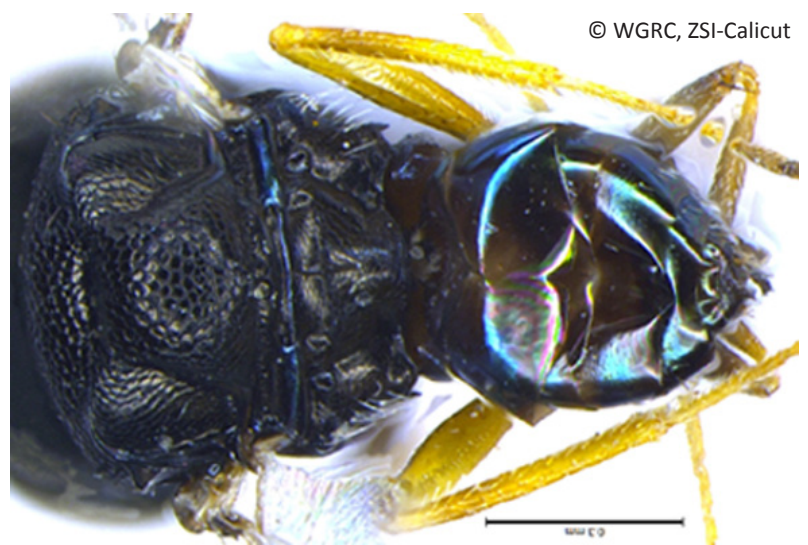

Image 5. Psilocera keralensis sp. nov. Body in part dorsal view.

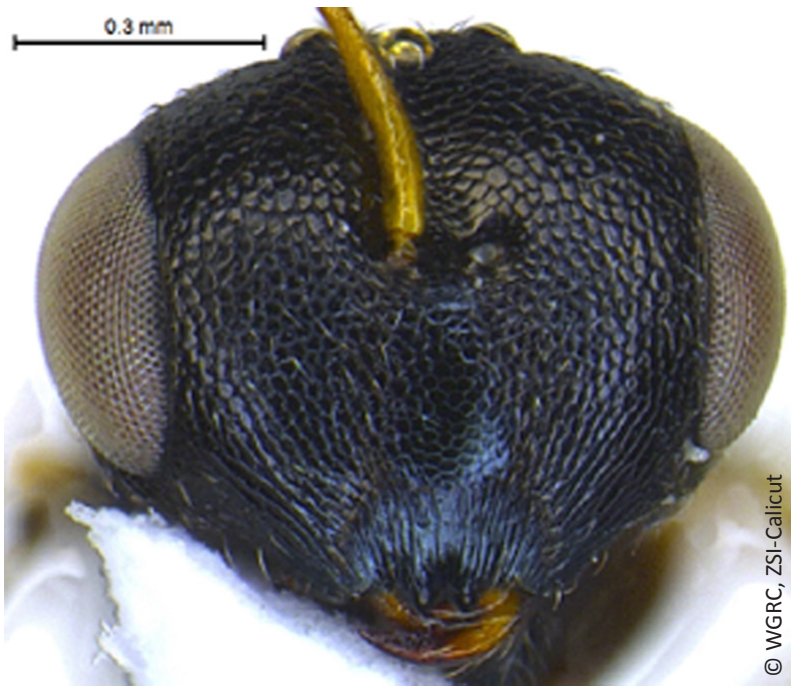

Image 7. Psilocera keralensis sp. nov. Male head in front view.

equal; scape reaching little below median ocellus, $0.72 \times$ eye height; pedicel $2 \times$ as long as broad, slightly shorter than anelli and F1 and F2 combined; F1 anelliform, as long as anelli, $1.4 \mathrm{x}$ as broad as long, and $0.3 \times$ as long as F2; F2 as long as F3; F4 slightly shorter than F3; F5 and F6 equal, slightly shorter than F4; funicular segments, except F1, with one row of long sensillae, pubescence long; clava $2 \times$ as long as broad, a little longer than 3.5 preceding segments combined, sutures oblique, area of micropilosity reaching base of second segment.

Mesosoma: (Image 5) convex with sparse white pubescence; scutellum with black bristles. Pronotum finely reticulate, collar narrow, anterior margin sharp edged. Mesoscutum 2.7x as broad as long with broad reticulation; notauli incomplete, distinct. Axilla almost shiny, finely aciculate. Scutellum highly convex, $1.3 \times$ as broad as long, with broad reticulation, reticulation on 
frenal area minute. Dorsellum narrow, finely reticulate. Propodeum medially $0.6 \times$ as long as scutellum, almost uniformly aciculate reticulate; callus with dense white hairs; median carina distinct, complete; costula weakly indicated, separated from anterior margin of propodeum by $0.25 \times$ of median length; nucha distinct; spiracles elongatedly ovate, separated from hind margin of metanotum by less than its diameter. Forewing length $2.2 \times$ width; basal part almost bare except a few hairs on basal vein; costal cell hairy towards tip; pubescence otherwise moderate; speculum open below; marginal fringe moderately long. Relative length of SMV, 25; MV 16.5; PMV, 11.5; STV, 6. Legs slender; hind tibia with two unequal spurs.

Metasoma (Image 5): Gaster $1.3 \times$ as long as broad, $0.64 \times$ as long as head plus mesosoma, dorsally collapsing; posterior margins of T1-T4 distinctly incised in the middle, T5 slightly emarginate.

Male: Length, $2.1 \mathrm{~mm}$. Resembles female but differs in having antenna with anelli small, strongly transverse; funicular segments pedunculate; F1 with two distinct whorls of long white hairs, rest of the segments with one whorl of long hairs. Gaster long, $0.8 \times$ as long as head plus mesosoma, brown, with a median yellow band dorsally reaching beyond half its length.

\section{Etymology}

The species name is derived from the name of the Kerala State (India) where the specimens were collected.

\section{Remarks}

In having antenna with first funicular segment anelliform without sensilla, smaller body size and male antenna with strongly pedunculate funicle segments, this species closely resembles $P$. obscurus (Walker) but differs from it in having the gaster with T4 more than $2 x$ as long as T3 in dorsal view; forewing with basal cell completely bare, and male flagellum with strongly pedunculate segments. (In $P$. obscurus: gaster with T4 shorter, as long as T3, in dorsal view; forewing with distal

Key to the oriental species of Psilocera Walker (females)

(Modified from Sureshan 2011)

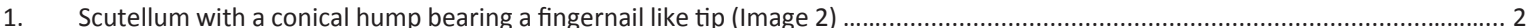

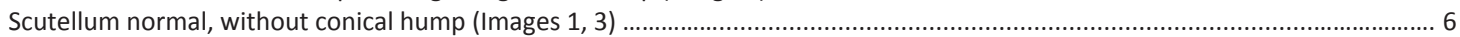

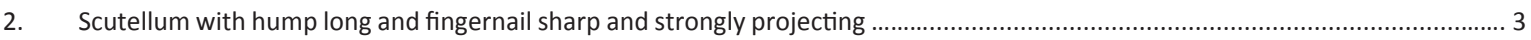
Scutellum with hump short, fingernail not much sharp and projecting as above ................................................................. 5

3. Forewing with basal cell hairy and closed below. (Brazil; Sri Lanka)................................................................ clavicornis (Ashmead) Forewing with basal cell not hairy as above, sometimes a few hairs at tip, and open below. ........................................................ 4

4. Antenna with pedicel as long as F1; clava shorter than 4 preceding segments combined; scape, pedicel, anelli and basal threefourths of F1 testaceous; gaster $1.72 \times$ as long as hind tibia and $0.9 \times$ rest of the body. (India).....

P. neoclavicornis Narendran \& Girish Kumar Pedicel almost 2x F1; clava longer than four preceding segments combined; F1 black as remainder of antenna; gaster $1.4 \times$ as long as hind tibia and $0.7 \times$ as long as rest of the body (India)

P. intermedia sp. nov.

5. Scutellar hump short, median length of scutellum up to tip of hump $0.73 \times$ length of mesoscutum; hind tibial spur long, almost half as long as basitarsus; forewing with PMV $0.72 \times$ as long as MV; eye short, height $1.6 \times$ width; gaster dorsally with metallic blue reflection; antenna with scape, pedicel and anelli brown; legs with femora brown (India) .................................P. heydoni Sureshan Scutellar hump long, median length of scutellum up to tip of hump $0.82 \times$ length of mesoscutum; hind tibial spur short, $0.3 \times$ as long as basitarsus; forewing with PMV 0.9× MV; eyes longer, height 1.9× width; gaster dorsally without blue reflection; antenna with scape, pedicel and anelli testaceous; femora testaceous (India)............................................................ scutellata Sureshan

6. Antenna with F1 short or anelliform, $1.2-1.4 \times$ as broad as long, and without sensilla; scape reaching far below level of median

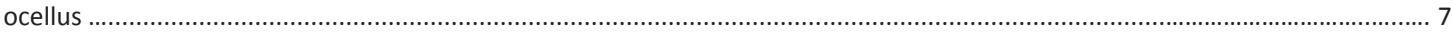
Antenna with F1 not short or anelliform, longer than broad, and with distinct sensilla; scape just short of reaching or just touching

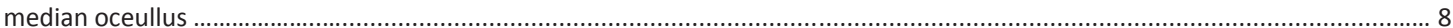

7. Antenna with F1 very short, anelliform, $0.3 \times$ as long as F2 and $1.4 \times$ as broad as long, flagellum with clava little swollen; antenna black except scape, pedicel and anelli testaceous (India) ................................................................................P. $\boldsymbol{P}$. keralensis sp. nov. Antenna with F1 not very short as above, $1.2 \times$ as broad as long and only little shorter than F2, clava highly swollen; antenna testaceous except clava black (India) .............................................................................................. P. clavata Sureshan \& Narendran

8. Malar groove not distinct; antenna with clava shorter than three preceding segments combined; gaster long, $0.93 \times$ as long as head plus mesosoma ; scutellum without long hairs or bristles. (Pakistan) ........................................................ P. ghanii Subba Rao Malar groove distinct; clava as long as or longer than three preceding segments combined; gaster $0.7-0.8 \times$ as long as head plus mesosoma combined; scutellum with long white hairs or black bristles

9. Clava as long as three preceding segments combined; scape reaching median ocellus; gaster, $0.8 \times$ as long as head plus mesosoma; scutellum with long white bristles (India) ............................................................................... P. vinayaki Sureshan \& Narendran Clava as long as preceding 3.5 segments combined ; scape just short of reaching median ocellus; gaster, $0.7 \times$ as long as head plus mesosoma ; scutellum with long black bristles (India) . P. namdaphaensis sp. nov. 
$0.25 \times$ to $0.5 \times$ of basal cell pilose, and male antenna with less pedunculate segments). Among the other species of Oriental region, this species resembles $P$. clavata Sureshan \& Narendran, in having F1 anelliform but $P$. clavata differs from the new species in having antenna with clava more swollen, F1 longer than broad (1.2x); antenna uniformly testaceous except black clava, and other characters as given in the key.

\section{REFERENCES}

Graham, M.W.R.de V. (1992). Second revision of western European Psilocera (Hymenoptera: Pteromalidae) with descriptions of three new species. Entomologists Monthly Magazine 128: 15-21.

ICZN (1999). International Code of Zoological Nomenclature, $4^{\text {th }}$ edition. International Trust for Zoological Nomenclature, London, xxi+306 pp.

ICZN (2012). Amendment of Articles 8, 9, 10, 21 and 78 of the International Code of Zoological Nomenclature to expand and refine methods of publication. Published by the International Commission on Zoological Nomenclature. Zootaxa 3450: 1-7.

Narendran, T.C. \& P.G. Kumar (2009). Three new species of Pteromalidae (Hymenoptera: Chalcidoidea) from Sunderbans,
West Bengal, India. Journal of Environment and Sociobiology 6(2): 123-130.

Noyes, J.S. (2012). Universal Chalcidoidea database. http://www.nhm. ac.uk/jdsml/research-curation/projects/chalcidoids/database. Accessed on $28^{\text {th }}$ May 2013.

Rao, B.R.S. (1981). Description of new species of Pteromalidae from the Orient (Hymenoptera: Chalcidoidea). Proceedings Indian Academy of Science. (B) 90: 473-482.

Sureshan, P.M. (2000). Taxonomic studies on Cyclogastrella Bukowski and Psilocera Walker (Hymenoptera: Chalcidoidea: Pteromalidae) with the description of a new species from the Oriental region. Hexapoda 12 ( 1\&2): 35-40.

Sureshan, P.M. (2001). Taxonomic studies on Psilocera from India with descriptions of two new species ( Hymenoptera : Chalcidoidea: Pteromalidae). Oriental Insects 35: 83-90.

Sureshan, P.M. (2011). A revision of Oriental species of Psilocera Walker (Hymenoptera: Chalcidoidea: Pteromalidae) with descriptions of two new species from Namdapha National Park, Arunachal Pradesh, India. International Scholarly Research Network ISRN Zoology Vol. 2011, Article ID 391796, 6pp; http://dx.doi. org/10.5402/2011/391796

Sureshan, P.M. \& T.C. Narendran (1995) Two new species of Psilocera (Hymenoptera: Chalcidoidea: Pteromalidae) from India. Journal of Ecobiology 17(3): 209-212. 